\title{
PENGARUH PEMBELAJARAN ILMU TAJWID BERBASIS MULTIMEDIA FLASH TERHADAP MOTIVASI BELAJAR SISWA KELAS X MADRASAH ALIYAH DARUL MASHOLEH KOTA CIREBON TAHUN AJARAN 2017/2018
}

\author{
M. Munawir Ghozali, Wawan Ahmad Ridwan, Suteja \\ Fakultas Ilmu Tarbiyah dan Keguruan \\ Institut Agama Islam Negeri Syekh Nurjati Cirebon \\ Email : mmunawirghozali612@gmail.com
}

\begin{abstract}
ABSTRAK
Madrasah Aliyah Darul Masholeh merupakan sekolah swasta yang berada di Kota Cirebon, Dalam Kegiatan Belajar Mengajar pada ilmu tajwid masih mengandalkan media buku sehingga pemahaman siswa dalam mempelajari ilmu tajwid masih belum optimal, hal itu terlihat dari sebagian siswa yang belum bisa memenuhi Kriteria Ketuntasan Minimum (KKM) dari hasil pembelajaran ilmu tajwid yang hanya menggunakan media pembelajaran buku.

Penelitian ini bertujuan untuk mengetahui penerapan media pembelajaran tajwid menggunakan multimedia flash di Madrasah Aliyah Darul Masholeh Kota Cirebon terhadap Motivasi belajar siswa sehingga bisa memenuhi Kriteria Ketuntasan Minimum (KKM).

Multimedia adalah suatu kombinasi berbagai tipe media (teks, gambar, audio, grafik, video, animasi dan lain sebagainya) yang disajikan, digabungkan menggunakan alat bantu (tool) dan koneksi (link), dan dikemas menjadi satu file digital (komputerisasi) yang bertujuan untuk menyampaikan, menghantarkan, dan menerima pesan atau informasi kepada pengguna atau publik.

Pengumpulan data ini menggunakan teknik : tes, observasi, wawancara, angket, postes dan pretes. Kemudian data di analisis dengan korelasi uji normalitas dan uji homogenitas.

Dari hasil analisis terhadap nilai motivasi belajar pada kelas Eksperimen. Dapat disimpulkan bahwasanya nilai tertinggi 83 Dan adapun
\end{abstract}


sekor yang paling kecil adalah 49. Secara keseluruhan dari hasil analisis terhadap motivasi belajar adalah 915 dan dengan nilai rata-rata keseluruhan adalah 61.

Kata Kunci: Motivasi Belajar, Multimedia Flash, Media Pembelajaran.

\begin{abstract}
Madrasah Aliyah Darul Masholeh is a private school located in Cirebon City, in Teaching and Learning Activities in science of tajwid still rely on book media so that students' understanding in learning science tajwid still not optimal, it can be seen from some students who have not fulfilled the Minimum Exhaustiveness Criteria (KKM ) from learning result of science of tajwid which only use instructional media of book.

This study aims to determine the application of learning media tajwid using flash multimedia in Madrasah Aliyah Darul Masholeh Cirebon City on student motivation so that it can meet the Minimum Exhaustiveness Criteria (KKM).

Multimedia is a combination of various types of media (text, images, audio, graphics, video, animation and so on) presented, combined using tools and links, and packaged into a digital file to convey, deliver, and receive messages or information to users or the public.

This data collection uses techniques: test, observation, interview, questionnaire, postes and pretes. Then the data in the analysis with the correlation test normality and homogeneity test.

From the results of the analysis of the value of learning motivation in the experimental class. It can be concluded that the highest score is 83 And the smallest score is 49. Overall the analysis of learning motivation is 915 and the overall average is 61 .
\end{abstract}

Keywords: Learning Motivation, Flash Multimedia, Learning Media. 


\section{PENDAHULUAN}

Yang dimaksud dengan ibadah mahdhah adalah hubungan manusia dengan Tuhannya, yaitu hubungan yang akrab dan suci antara seorang muslim dengan Allah SWT yang bersifat ritual (peribadatan), Ibadah mahdhah merupakan manifestasi dari rukun islam yang lima. Atau juga sering disebut ibadah yang langsung. Selain itu juga ibadah mahdhah adalah ibadah yang perintah dan larangannya sudah jelas secara zahir dan tidak memerlukan penambahan atau pengurangan. Jenis ibadah yang termasuk ibadah mahdhah, adalah :

1. Shalat

Secara lughawi atau arti kata shalat mengandung beberapa arti yang beragam salah satunya do'a, itu dapat ditemukan contohnya dalam Al-Qur'an surat alوصل عليهم إن صلوتلك سكن لهم:103 Taubah ayat

Berdo'alah untuk mereka, sesungguhnya do'a kamu itu (menjadi) ketentraman jiwa bagi mereka.Secara terminologis ditemukan beberapa istilah diantarnya: "Serangkaian perkataan dan perbuatan tertentu yang dimulai dengan takbir dan disudahi salam".

2. Zakat

Zakat adalah salah satu ibadah pokok dan termasuk salah satu rukun Islam, yang berarti membersihkan, bertumbuh dan berkah. Zakat itu ada dua macam: yaitu zakat harta atau disebut juga zakat mal dan zakat diri yang dikeluarkan setiap akhir bulan ramadhan yang disebut juga zakat fitrah.

3. Puasa

Puasa adalah ibadah pokok yang ditetapkan sebagai salah satu rukun Islam. Puasa secara bahasa bermakna, menahan dan diam dalam segala bentuknya. Secara terminologis puasa diartikan dengan "menahan diridari makan, minum dan berhubungan seksual mulai dari terbit fajar sampai terbenam matahari dengan syarat-syarat yang ditentukan”.

4. IbadahHaji

Secara arti kata, lafaz haji yang berasal dari bahasa arab, berarti "bersengaja". Dalam artian terminologis adalah Menziarahi ka'bah dengan melakukan 
serangkaian ibadah di Masjidil Haram dan sekitarnya, baik dalam bentuk haji ataupun umroh.

5. Umroh

Umroh adalah mengunjungi ka'bah dengan serangkaian khusus disekitarnya. Perbedaannya dengan haji ialah bahwa padanya tidak ada wuquf di Arafah, berhenti di Muzdalifah, melempar jumrah dan menginap di Mina. Dengan begitu ia merupakan haji dalam bentuknya yang lebih sederhana, sehingga sering umroh itu disebut dengan haji kecil.

6. Bersuci dari hadas kecil maupun besar.

Rumusan Ibadah Mahdhah adalah “KA + SS”(Karena Allah + Sesuai Syari' at)

Salah satu Ibadah Mahdoh adalah Shalat, Menurut bahasa shalat artinya adalah berdoa, sedangkan menurut istilah shalat adalah suatu perbuatan serta perkataan yang dimulai dengan takbir dan diakhiri dengan salam sesuai dengan persyaratkan yang ada.

Secara lahiriah shalat berarti beberapa ucapan dan perbuatan yang dimulai dengan takbir dan diakhiri dengan salam, yang dengannya kita beribadah kepada Allah menurut syarat-syarat yang telah ditentukan. Adapun secara hakikinya ialah" berhadapan hati (jiwa) kepada Allah, secara yang mendatangkan takut kepada-Nya serta menumbuhkan didalam jiwa rasa kebesarannya dan kesempurnaan kekuasaan-Nya"atau" mendahirkan hajat dan keperluan kita kepada Allah yang kita sembah dengan perkataan dan pekerjaan atau dengan kedua-duanya.

Dalam pelaksanaan shalat itu membaca ayat-ayat dalam Al Qur'an, dalam membaca Al Qur'an harus menggunakan kaidah bacaan yang di tentukan (Tajwid).

Menurut survei dilapangan, banyak permasalahan yang di alami oleh siswa yaitu malas belajar, tajwid di anggap susah dan terlalu rumit. Sehingga dibutuhkan media pembelajaran yang tepat untuk meningkatkan motivasi belajar siswa terhadap ilmu tajwid, dan media yang tepat untuk meningkatkan motivasi belajar siswa terhadap ilmu tajwid adalah media pembelajaran multimedia flash, 
karena dengan multimedia flash siswa dapat langsung berinteraksi dan didukung pula dengan tampilan animasi yang membuat siswa tidak jenuh.

\section{PEMBAHASAN}

Motivasi berasal dari kata "motif' yang diartikan sebagai " daya penggerak yang telah menjadi aktif" (Sardiman,2005).

Dalam buku psikologi pendidikan Dalyono memaparkan bahwa "motivasi adalah daya penggerak/pendorong untuk melakukan sesuatu pekerjaan, yang bisa berasal dari dalam diri dan juga dari luar" (Dalyono, 2005).

Ngalim Purwanto, Sartainmengatakan bahwa motivasi adalah suatu pernyataan yang kompleks di dalam suatu organisme yang mengarahkan tingkah laku terhadap suatu tujuan (goal) atau perangsang (incentive). Tujuan adalah yang membatasi/menentukan tingkah laku organisme itu (Ngalim Purwanto, 2007).

Dengan demikian motivasi dalam prosespembelajaran sangat dibutuhkan untuk terjadinya percepatan dalam mencapai tujuan pendidikan dan pembelajaran secara khusus.

Kemampuan untuk berhasil belajar merupakan suatu puncak proses belajar. Pada tahap ini siswa membuktikan keberhasilan belajar. Keberhasilan tersebut dapat dicapai dengan memperhatikan materi yang sedang guru sampaikan, seorang guru harus mampu membuat suasana belajar tersebut mengasyikan dan memberi kesempatan siswa untuk aktif dalam proses pembelajaran.

Selain itu siswa dapat menunjukan bahwa ia telah mampu memecahkan tugas-tugas belajar atau mentransfer hasil belajar. Dari pengalaman sehari-hari di sekolah diketahui bahwa ada sebagian siswa yang tidak mampu berprestasi dengan baik. Kemampuan berprestasi tersebut terpengaruhi oleh penerimaan, pengolahan, penyimpanan serta pemanggilan untuk pembangkitan pesan dan pengalaman. Bila proses tersebut tidak baik maka prestasi siswa juga akan kurang baik (Dimiyati dan Mudjiono, 2006).

Adapun hubungan antara media pembelajaran tajwid berbasis multimedia flash dengan motivasi belajar siswa yaitu siswa dapat lebih memahami materi 
yang disampaikan oleh guru karena pada media pembelajaran tajwid berbasis multi media merangsang siswa untuk aktif dalam kegiatan belajar mengajar.

Ilmu tajwid merupakan ilmu yang digunakan untuk mengetahui bagaimana sebenarnya membunyikan huruf-huruf dengan benar, baik huruf yang berdiri sendiri maupun huruf yang dalam rangkaian.(Abdullah Asy’ari.1987)

Sedangkan pendapat lain mengatakan bahwa ilmu tajwid menurut Bahasa adalah perbaikan, penyempurnaan ataupemantapan. Dikatakan bagi orang yang baik dalam bacaan Al-Qur'an dengan mujawwid. Sedangkan menurut istilah adalah Keluarnya semua huruf hijaiyah dari makhrajnya (tempat keluarnya huruf) dengan memberikan haq dan keharusannya dari sifat tersebut. (Abu Hazim Muhsin Bin Muhammad Bashory, 2008)

Jadi ilmu tajwid merupakan ilmu yang membahas tata cara mengucapkan setiap huruf atau tata cara membaca al-Qur'an dengan baik dan benar yang dikenal dalam membaca Al-Qur'an dengan tartil.

Tempat atau lokasi penelitian yang dilakukan oleh peneliti adalah MA Darul Masholeh yang bertempat di Jl. Kedung Menjangan Kota. Cirebon. Penelitian telah dilaksanakan selama 1 bulan yaitu dari tanggal 01 November 2017 sampai 01Desember 2017. Peneliti melakukan penelitian di MA Darul Masholeh karena sekolah ini memiliki fasilitas yang bisa mendukung berjalannya media pembelajaran menggunakan Multimedia seperti infocus dan Komputer.

Untuk mendapatkan data yang diperlukan oleh peneliti maka digunakan metode sebagai berikut:

a. Angket

"Angket adalah sejumlah pertanyaan tertulis yang digunakan untuk memperoleh informasi dari responden dalam arti laporan tentang pribadinya, atau hal-hal yang ia ketahui" (Arikunto, 2010). Dalam penelitian ini angket digunakan untuk mengetahui motivasi belajar siswa Madrasah Aliyah Darul Masholeh Kota Cirebon.

b. Dokumentasi 
Suharsimi Arikunto menjelaskan bahwa metode dokumentasi adalah mencari data mengenai hal- hal yang variabelnya berupa catatan, transkip, buku, surat kabar, majalah, prasasti, notulen rapat, leger, agenda dan lain sebagainya (Suharsimi Arikunto, 2002).

Penelitian dibagi menjadi dua kelompok yaitu Kelas Eksperimen dan Kelas Kontrol. Peneliti mengambil kelas X IPS menjadi kelas Kontrol yang berjumlah 14 siswa. Dan untuk Kelas Eksperimen peneliti mengambil kelas X IPA sebagai Kelas Eksperimen yang berjumlah 15 siswa.

Berikut adalah hasil penilaian pada kelas eksperimen sebelum menggunakan multimedia flash dan control tidak menggunakan multimedia flash di MA Darul Masholeh Kota Cirebon.

\begin{tabular}{|c|c|c|c|c|c|c|c|c|c|c|c|c|c|c|c|c|c|c|c|c|c|c|}
\hline \multirow{2}{*}{ No } & \multirow{2}{*}{ Nama } & \multicolumn{20}{|c|}{ Pernyataan } & \multirow{2}{*}{ Skor } \\
\hline & & 1 & 2 & 3 & 4 & 5 & 6 & 7 & 8 & 9 & 10 & 11 & 12 & 13 & 14 & 15 & 16 & 17 & 18 & 19 & 20 & \\
\hline 1 & Ayu Zihan Fadilah & 4 & 3 & 2 & 3 & 2 & 1 & 2 & 3 & 5 & 4 & 3 & 4 & 5 & 4 & 3 & 4 & 3 & 4 & 3 & 5 & 67 \\
\hline 2 & Ahmah Wati & 2 & 4 & 4 & 4 & 3 & 3 & 5 & 5 & 3 & 1 & 1 & 1 & 5 & 4 & 1 & 1 & 2 & 3 & 5 & 2 & 59 \\
\hline 3 & Arum Puspita W & 5 & 1 & 4 & 2 & 2 & 3 & 4 & 5 & 5 & 4 & 2 & 1 & 3 & 5 & 3 & 4 & 3 & 4 & 4 & 4 & 68 \\
\hline 4 & Arif Rifa'i & 2 & 4 & 5 & 4 & 5 & 3 & 5 & 4 & 3 & 3 & 4 & 1 & 4 & 3 & 2 & 2 & 4 & 2 & 2 & 3 & 65 \\
\hline 5 & Fadilah A. & 2 & 4 & 4 & 4 & 3 & 1 & 5 & 5 & 3 & 1 & 1 & 1 & 5 & 1 & 1 & 1 & 3 & 3 & 3 & 1 & 52 \\
\hline 6 & Hani Sintyani & 4 & 4 & 3 & 4 & 3 & 1 & 5 & 5 & 3 & 1 & 3 & 2 & 5 & 3 & 2 & 1 & 5 & 4 & 4 & 2 & 64 \\
\hline 7 & Susanti & 5 & 5 & 5 & 5 & 5 & 5 & 5 & 5 & 5 & 5 & 5 & 5 & 4 & 5 & 5 & 5 & 3 & 3 & 3 & 4 & 92 \\
\hline 8 & Pandu Prakoso & 3 & 2 & 4 & 1 & 3 & 2 & 3 & 3 & 4 & 5 & 4 & 3 & 4 & 5 & 3 & 3 & 4 & 2 & 2 & 3 & 63 \\
\hline 9 & Mulyana & 3 & 1 & 2 & 3 & 1 & 3 & 2 & 1 & 5 & 4 & 5 & 4 & 3 & 3 & 3 & 3 & 3 & 3 & 4 & 5 & 61 \\
\hline 10 & Lintang Kerri & 3 & 3 & 3 & 2 & 2 & 2 & 4 & 3 & 3 & 3 & 3 & 3 & 2 & 2 & 3 & 2 & 2 & 4 & 3 & 4 & 56 \\
\hline 11 & Ninis Umaelina & 3 & 3 & 3 & 3 & 3 & 4 & 5 & 4 & 5 & 5 & 5 & 3 & 5 & 3 & 3 & 3 & 4 & 3 & 2 & 3 & 72 \\
\hline 12 & Yuni Fatamawati & 3 & 5 & 4 & 2 & 1 & 3 & 5 & 4 & 3 & 4 & 2 & 3 & 5 & 4 & 3 & 3 & 5 & 4 & 4 & 2 & 69 \\
\hline 13 & Handika & 3 & 4 & 2 & 3 & 4 & 3 & 3 & 3 & 5 & 4 & 3 & 4 & 3 & 3 & 4 & 5 & 4 & 3 & 3 & 4 & 70 \\
\hline 14 & Rafi & 2 & 3 & 1 & 2 & 1 & 2 & 1 & 1 & 4 & 5 & 3 & 3 & 4 & 4 & 3 & 3 & 3 & 4 & 5 & 3 & 57 \\
\hline
\end{tabular}

Dari hasil analisis terhadap nilai pretes motivasi belajar pada kelas Kontrol. Dapat disimpulkan bahwasanya skor yang paling besar adalah pada pernyataan atau butir no 13 yaitu Saya selalu memberikan pendapat saat diskusi mengenai materi ilmu tajwid. Dengan nilai rata- rata 4,07. Dan adapun sekor yang paling kecil adalah pernyataan atau butir no 6 yaitu Setiap menemukan kesulitan dalam materi tajwid, saya selalu bertanya pada guru/ustadz yang bersangkutan. Dengan nilai rata - rata 2,57. Secara keseluruhan dari hasil analisis terhadap motivasi belajar adalah 915 dan dengan nilai rata-rata keseluruhan adalah 65,357. 


\begin{tabular}{|c|c|c|c|c|c|c|c|c|c|c|c|c|c|c|c|c|c|c|c|c|c|c|}
\hline \multirow{2}{*}{ No } & \multirow{2}{*}{ Nama } & \multicolumn{20}{|c|}{ Pernyataan } & \multirow{2}{*}{ Skor } \\
\hline & & 1 & 2 & 3 & 4 & 5 & 6 & 7 & 8 & 9 & 10 & 11 & 12 & 13 & 14 & 15 & 16 & 17 & 18 & 19 & 20 & \\
\hline 1 & Agung Suhendi & 4 & 3 & 3 & 3 & 3 & 3 & 4 & 2 & 4 & 4 & 2 & 2 & 4 & 2 & 2 & 3 & 3 & 4 & 2 & 3 & 60 \\
\hline 2 & Aris & 4 & 3 & 2 & 4 & 3 & 2 & 5 & 3 & 4 & 2 & 3 & 1 & 4 & 2 & 3 & 2 & 2 & 3 & 2 & 3 & 57 \\
\hline 3 & Ayu Sugiaru & 3 & 5 & 2 & 4 & 1 & 3 & 4 & 2 & 3 & 4 & 1 & 5 & 2 & 3 & 5 & 3 & 4 & 2 & 3 & 3 & 62 \\
\hline 4 & Cahya Ramadan & 4 & 3 & 2 & 3 & 3 & 3 & 4 & 3 & 3 & 4 & 4 & 3 & 2 & 2 & 3 & 2 & 3 & 3 & 3 & 2 & 59 \\
\hline 5 & Dian Putri Kusumawati & 4 & 3 & 2 & 2 & 5 & 4 & 5 & 2 & 2 & 1 & 3 & 2 & 4 & 1 & 1 & 4 & 2 & 2 & 3 & 4 & 56 \\
\hline 6 & Dini & 4 & 5 & 5 & 3 & 4 & 2 & 5 & 3 & 3 & 3 & 3 & 1 & 1 & 3 & 2 & 3 & 3 & 4 & 3 & 5 & 65 \\
\hline 7 & Halvari Amri & 1 & 3 & 2 & 4 & 5 & 4 & 3 & 2 & 4 & 1 & 4 & 3 & 4 & 5 & 2 & 3 & 2 & 3 & 2 & 3 & 60 \\
\hline 8 & Muhamad Nur Irzan & 4 & 3 & 2 & 2 & 3 & 3 & 4 & 2 & 3 & 3 & 4 & 3 & 3 & 2 & 3 & 4 & 3 & 2 & 4 & 4 & 61 \\
\hline 9 & Nova Kristiana & 3 & 4 & 4 & 3 & 3 & 1 & 2 & 3 & 3 & 5 & 3 & 3 & 4 & 5 & 3 & 4 & 2 & 3 & 3 & 2 & 63 \\
\hline 10 & Nur'aeni & 5 & 5 & 3 & 3 & 4 & 3 & 5 & 4 & 5 & 3 & 3 & 4 & 3 & 3 & 2 & 3 & 2 & 2 & 2 & 3 & 67 \\
\hline 11 & Reza Adi Pratama & 2 & 1 & 1 & 1 & 1 & 1 & 3 & 3 & 3 & 3 & 4 & 3 & 3 & 3 & 3 & 3 & 3 & 4 & 3 & 4 & 52 \\
\hline 12 & Risnawati & 4 & 5 & 4 & 4 & 5 & 4 & 5 & 5 & 5 & 4 & 4 & 4 & 5 & 5 & 3 & 4 & 2 & 3 & 4 & 4 & 83 \\
\hline 13 & Rizal Purnama & 3 & 1 & 3 & 2 & 1 & 2 & 1 & 3 & 3 & 4 & 3 & 2 & 3 & 4 & 2 & 2 & 1 & 2 & 2 & 5 & 49 \\
\hline 14 & Siti Rohmah & 5 & 3 & 2 & 2 & 3 & 2 & 4 & 4 & 5 & 3 & 5 & 1 & 5 & 3 & 4 & 4 & 2 & 3 & 4 & 4 & 68 \\
\hline 15 & Widi Sopyana & 3 & 1 & 3 & 1 & 2 & 4 & 3 & 3 & 2 & 3 & 3 & 2 & 2 & 4 & 3 & 3 & 2 & 3 & 3 & 3 & 53 \\
\hline
\end{tabular}

Dari hasil analisis terhadap nilai pretes motivasi belajar pada kelas Eksperimen. Dapat disimpulkan bahwasanya skor yang paling besar adalah pada pernyataan atau butir no 7 yaitu Setelah mendapatkan pembelajaran ilmu tajwid, saya suka mencari bacaan- bacaan dalam al-qur'an dengan nilai rata- rata 3,8. Dan adapun sekor yang paling kecil adalah pernyataan atau butir no 3 yaitu Saya akan mencari sumber-sumber lain untuk melengkapi pemahaman saya tentang materi tajwid. dengan nilai rata - rata 2,67. Secara keseluruhan dari hasil analisis terhadap motivasi belajar adalah 915 dan dengan nilai rata-rata keseluruhan adalah 61 .

Untuk mengetahui apakah terdapat perbedaan Motivasi Belajaryang signifikan atau tidak antara kelompok control dan eksperimen sebelum pembelajaran,maka dihitung menggunakan ketentuan sebagai berikut:

$$
\begin{aligned}
& \mathrm{H} 0: \mu 0=\mu 1 \\
& \text { H1 }: \mu 1 \neq \mu 0
\end{aligned}
$$

Adapun kriteria yang digunakan untuk melihat diterima atau tidaknya H0 adalah berdasarkan koefisien signifikansi sebagai berikut. Koefisien Signifikansi adalah koefisien yang dihasilkan dari perhitungan uji u 
Jika koefisien signifikansi $<\alpha$, maka $\mathrm{H} 0$ ditolak

Jika koefisien signifikansi $\geq \alpha$, maka $\mathrm{H} 0$ diterima

Keterangan:

$\alpha=$ derajat margin of eror besarnya $0,5 \% / 0,05$.

\section{Mann-Whitney Test}

\section{Ranks}

\begin{tabular}{|ll|r|r|r|}
\hline \multicolumn{1}{|c|}{ Kelompok } & \multicolumn{1}{|c|}{ N } & Mean Rank & Sum of Ranks \\
\hline Nilai & Pretest Kontrol & 14 & 17.46 & 244.50 \\
& Pretest & 15 & 12.70 & 190.50 \\
Eksperimen & 29 & & \\
Total & & \\
\hline
\end{tabular}

\section{Test Statistics ${ }^{\mathrm{b}}$}

\begin{tabular}{|l|r|}
\hline & \multicolumn{1}{|c|}{ Nilai } \\
\hline Mann-Whitney U & 70.500 \\
Wilcoxon W & 190.500 \\
Z & -1.508 \\
Asymp. Sig. (2-tailed) & .132 \\
Exact Sig. [2*(1-tailed & $.134^{\mathrm{a}}$ \\
Sig.)] & \\
\hline
\end{tabular}

a. Not corrected for ties.

b. Grouping Variable: Kelompok

Berdasarkan table diatas dapat diambil kesimpulan dari hasil hitung antara nilai pretes kelompok control dengan nilai pretes kelompok eksperimen sebelum menggunakan multimedia flash.

Dari hasil analisis sebelum menggunakan multimedia flashterhadap nilai pretes motivasi belajar pada kelas Kontrol dan Kelas Eksperimendapat diambil kesimpulan bahwasanya nilai pretes kelompok control dengan jumlah keseluruhan nilai yaitu 244,50 dengan nilai rata- rata 17,46. Sedangkan Nilai Pretes kelompok 
Eksperimen keseluruhan nilai yaitu 190,50 dengan nilai rata- rata 12,70. Jadi dapat diambil kesimpulan antara nilai pretes kontrol dan nilai pretes eksperimen setelah dihitung menggunakan uji U hasilnya tidak signifikan.

Penelitian dibagi menjadi dua kelompok yaitu Kelas Eksperimen dan Kelas Kontrol. Peneliti mengambil kelas X IPS menjadi kelas Kontrol yang berjumlah 14 siswa. Dan untuk Kelas Eksperimen peneliti mengambil kelas X IPA sebagai Kelas Eksperimen yang berjumlah 15 siswa.

Berikut adalah hasil penilaian pada kelas eksperimen sesudah menggunakan multimedia flash dan control tidak menggunakan multimedia flash di MA Darul Masholeh Kota Cirebon.

\begin{tabular}{|c|c|c|c|c|c|c|c|c|c|c|c|c|c|c|c|c|c|c|c|c|c|c|}
\hline \multirow{2}{*}{ No } & \multirow{2}{*}{ Nama } & \multicolumn{20}{|c|}{ Pernyataan } & \multirow{2}{*}{ Skor } \\
\hline & & 1 & 2 & 3 & 4 & 5 & 6 & 7 & 8 & 9 & 10 & 11 & 12 & 13 & 14 & 15 & 16 & 17 & 18 & 19 & 20 & \\
\hline 1 & Ayu Zihan Fadilah & 3 & 3 & 4 & 5 & 4 & 3 & 5 & 4 & 2 & 4 & 5 & 3 & 2 & 4 & 3 & 2 & 3 & 3 & 5 & 3 & 70 \\
\hline 2 & Ahmah Wati & 3 & 3 & 2 & 3 & 3 & 3 & 5 & 5 & 4 & 3 & 4 & 2 & 5 & 5 & 1 & 1 & 2 & 5 & 3 & 4 & 66 \\
\hline 3 & Arum Puspita W & 5 & 4 & 3 & 5 & 2 & 3 & 4 & 5 & 4 & 3 & 4 & 2 & 5 & 5 & 3 & 4 & 3 & 4 & 5 & 3 & 76 \\
\hline 4 & Arif Rifa'i & 5 & 4 & 3 & 3 & 4 & 2 & 5 & 4 & 4 & 4 & 3 & 2 & 3 & 4 & 2 & 2 & 4 & 2 & 5 & 3 & 68 \\
\hline 5 & Fadilah Angraeni & 3 & 3 & 4 & 1 & 2 & 4 & 5 & 5 & 2 & 2 & 1 & 2 & 2 & 5 & 1 & 1 & 5 & 3 & 5 & 5 & 61 \\
\hline 6 & Hani Sintyani & 5 & 4 & 3 & 5 & 4 & 2 & 5 & 5 & 3 & 3 & 2 & 3 & 2 & 3 & 2 & 1 & 4 & 5 & 3 & 4 & 68 \\
\hline 7 & Susanti & 2 & 3 & 4 & 3 & 2 & 4 & 3 & 2 & 4 & 5 & 2 & 2 & 4 & 5 & 3 & 2 & 3 & 3 & 3 & 4 & 63 \\
\hline 8 & Pandu Prakoso & 5 & 5 & 5 & 5 & 5 & 5 & 5 & 5 & 5 & 5 & 5 & 5 & 3 & 5 & 5 & 5 & 4 & 4 & 2 & 3 & 91 \\
\hline 9 & Mulyana & 2 & 3 & 4 & 3 & 2 & 3 & 4 & 3 & 4 & 2 & 3 & 2 & 3 & 3 & 3 & 4 & 4 & 2 & 3 & 4 & 61 \\
\hline 10 & Lintang Kerri & 3 & 3 & 4 & 3 & 3 & 2 & 3 & 4 & 2 & 3 & 3 & 2 & 3 & 3 & 3 & 3 & 5 & 3 & 2 & 3 & 60 \\
\hline 11 & Ninis Umaelina & 3 & 4 & 4 & 3 & 3 & 4 & 3 & 5 & 2 & 2 & 3 & 3 & 2 & 3 & 3 & 3 & 3 & 4 & 3 & 3 & 63 \\
\hline 12 & Yuni Fatamawati & 2 & 4 & 3 & 4 & 2 & 3 & 4 & 5 & 4 & 3 & 4 & 4 & 3 & 4 & 4 & 3 & 4 & 5 & 4 & 4 & 73 \\
\hline 13 & Handika & 3 & 4 & 5 & 3 & 4 & 3 & 4 & 5 & 4 & 3 & 3 & 3 & 3 & 4 & 4 & 4 & 2 & 4 & 4 & 2 & 71 \\
\hline 14 & Rafi & 3 & 4 & 2 & 3 & 4 & 5 & 4 & 3 & 4 & 3 & 4 & 3 & 3 & 3 & 2 & 4 & 4 & 3 & 3 & 3 & 67 \\
\hline
\end{tabular}

Dari hasil analisis terhadap nilai postes motivasi belajar pada kelas Kontrol. Dapat disimpulkan bahwasanya skor yang paling besar adalah pada pernyataan atau butir no 8 yaitu Saya bersemangat mendengarkan guru ketika sedang menerangkan materi ilmu tajwid. Dengan nilai rata- rata 4,28. Dan adapun sekor yang paling kecil adalah pernyataan atau butir no 12 yaitu Saya lebih suka dibantu teman dalam menentukan hukum ilmu tajwid pada bacaan Al-Qur'an. Dengan nilai rata - rata 2,714. Secara keseluruhan dari hasil analisis terhadap motivasi belajar adalah 958 dan dengan nilai rata-rata keseluruhan adalah 68,42. 


\begin{tabular}{|c|c|c|c|c|c|c|c|c|c|c|c|c|c|c|c|c|c|c|c|c|c|c|}
\hline \multirow{2}{*}{ No } & \multirow{2}{*}{ Nama } & \multicolumn{20}{|c|}{ Pernyataan } & \multirow{2}{*}{ Skor } \\
\hline & & 1 & 2 & 3 & 4 & 5 & 6 & 7 & 8 & 9 & 10 & 11 & 12 & 13 & 14 & 15 & 16 & 17 & 18 & 19 & 20 & \\
\hline 1 & Agung Suhendi & 5 & 5 & 4 & 4 & 3 & 5 & 4 & 3 & 4 & 5 & 5 & 5 & 6 & 5 & 4 & 5 & 3 & 2 & 3 & 4 & 84 \\
\hline 2 & Aris & 5 & 4 & 5 & 4 & 5 & 5 & 4 & 4 & 5 & 4 & 5 & 4 & 5 & 4 & 5 & 4 & 4 & 3 & 4 & 5 & 88 \\
\hline 3 & Ayu Sugianu & 5 & 5 & 4 & 5 & 4 & 5 & 5 & 5 & 5 & 3 & 4 & 5 & 5 & 5 & 5 & 4 & 3 & 4 & 5 & 2 & 88 \\
\hline 4 & Cahya Ramadan & 5 & 5 & 4 & 5 & 3 & 5 & 4 & 4 & 5 & 4 & 5 & 4 & 5 & 4 & 4 & 5 & 5 & 2 & 4 & 3 & 85 \\
\hline 5 & Dian Putri Kusumawati & 5 & 4 & 5 & 5 & 3 & 4 & 5 & 5 & 5 & 4 & 3 & 5 & 5 & 4 & 5 & 5 & 4 & 5 & 3 & 4 & 88 \\
\hline 6 & Dini & 5 & 4 & 5 & 5 & 5 & 4 & 5 & 3 & 5 & 3 & 5 & 3 & 5 & 5 & 4 & 5 & 3 & 3 & 3 & 5 & 85 \\
\hline 7 & Halvari Amri & 5 & 4 & 5 & 3 & 4 & 5 & 5 & 5 & 5 & 5 & 5 & 4 & 5 & 5 & 5 & 4 & 2 & 5 & 5 & 3 & 89 \\
\hline 8 & Muhamad Nur Irzan & 4 & 5 & 5 & 5 & 5 & 5 & 4 & 3 & 4 & 5 & 5 & 5 & 5 & 5 & 4 & 4 & 3 & 3 & 4 & 4 & 87 \\
\hline 9 & Nova Kristiana & 4 & 5 & 5 & 4 & 5 & 4 & 3 & 5 & 5 & 5 & 5 & 5 & 5 & 5 & 3 & 5 & 4 & 4 & 4 & 4 & 89 \\
\hline 10 & Nur'aeni & 5 & 5 & 4 & 4 & 5 & 4 & 5 & 4 & 5 & 5 & 3 & 4 & 2 & 5 & 5 & 5 & 3 & 3 & 4 & 3 & 83 \\
\hline 11 & Reza Adi Pratama & 5 & 5 & 3 & 3 & 5 & 4 & 3 & 5 & 5 & 5 & 3 & 5 & 5 & 5 & 5 & 5 & 3 & 3 & 5 & 5 & 87 \\
\hline 12 & Risnawati & 4 & 4 & 4 & 5 & 4 & 4 & 4 & 4 & 4 & 5 & 5 & 5 & 5 & 5 & 4 & 4 & 4 & 4 & 3 & 5 & 86 \\
\hline 13 & Rizal Purnama & 4 & 5 & 4 & 5 & 5 & 5 & 5 & 5 & 5 & 4 & 5 & 3 & 5 & 5 & 5 & 5 & 4 & 5 & 5 & 3 & 92 \\
\hline 14 & Siti Rohmah & 4 & 5 & 4 & 3 & 5 & 5 & 5 & 5 & 4 & 5 & 5 & 5 & 4 & 5 & 5 & 4 & 5 & 4 & 4 & 4 & 90 \\
\hline 15 & Widi Sopyana & 4 & 5 & 5 & 3 & 5 & 5 & 4 & 5 & 5 & 4 & 5 & 4 & 5 & 5 & 5 & 5 & 4 & 3 & 3 & 4 & 88 \\
\hline
\end{tabular}

Dari hasil analisis terhadap nilai postes motivasi belajar pada kelas Eksperimen. Dapat disimpulkan bahwasanya skor yang paling besar adalah pada pernyataan atau butir no 13 yaitu selalu memberikan pendapat saat diskusi mengenai materi ilmu tajwid, dengan nilai rata- rata 4,8. Dan butir 14 yaitu Jika ada pendapat yang berbeda mengenai ilmu tajwid, maka saya akan menanggapinya, dengan nilai rata- rata 4,8. Dan adapun sekor yang paling kecil adalah pernyataan atau butir no 18 yaitu Saya tertantang untuk mengerjakan soal-soal materi ilmu tajwid yang dianggap sulit oleh teman.dengan nilai rata - rata 3,53. Secara keseluruhan dari hasil analisis terhadap motivasi belajar adalah 1309 dan dengan nilai rata-rata keseluruhan adalah 87,26.

Untuk mengetahui apakah terdapat perbedaan Motivasi Belajaryang signifikan atau tidak antara kelompok control dan eksperimen setelah pembelajaran,maka dihitung menggunakan ketentuan sebagai berikut:

$$
\begin{aligned}
& \text { H0 }: \mu 0=\mu 1 \\
& \text { H1 }: \mu 1 \neq \mu 0
\end{aligned}
$$

Keterangan:

$$
\begin{array}{ll}
\mu 0 & =\text { skor posttest } \text { kelompok kontrol } \\
\mu 1 & =\text { skor posttest kelompok eksperimen }
\end{array}
$$


Adapun kriteria yang digunakan untuk melihat diterima atau tidaknya H0 adalah berdasarkan koefisien signifikansi sebagai berikut. Koefisien Signifikansi adalah koefisien yang dihasilkan dari perhitungan uji u

Jika koefisien signifikansi $<\alpha$, maka $\mathrm{H} 0$ ditolak

Jika koefisien signifikansi $\geq \alpha$, maka H0 diterima

Keterangan:

$\alpha=$ derajat margin of eror besarnya $0,5 \% / 0,05$.

\section{Mann-Whitney Test}

\begin{tabular}{|ll|r|r|r|}
\hline \multicolumn{6}{|c}{ Ranks } \\
\hline Kelompok & \multicolumn{1}{|c|}{ N } & Mean Rank & Sum of Ranks \\
\hline Nilai & Postes Kontrol & 14 & 8.50 & 119.00 \\
& Postes Eksperimen & 15 & 21.07 & 316.00 \\
& Total & 29 & & \\
\hline
\end{tabular}

Test Statistics ${ }^{b}$

\begin{tabular}{|l|r|}
\hline & \multicolumn{1}{|c|}{ Nilai } \\
\hline Mann-Whitney U & 14.000 \\
Wilcoxon W & 119.000 \\
Z & -3.979 \\
Asymp. Sig. (2-tailed) & .000 \\
Exact Sig. [2*(1-tailed & $.000^{\mathrm{a}}$ \\
Sig.)] & \\
\hline
\end{tabular}

a. Not corrected for ties.

b. Grouping Variable: Kelompok

Berdasarkan table diatas dapat diambil kesimpulan dari hasil hitung antara nilai postes kelompok kontrol yang tidak menggunakan multimedia flash dengan nilai postes kelompok eksperimen sesudah menggunakan multimedia flash.

Dari hasil analisis setelah menggunakan multimedia flashterhadap nilai postes motivasi belajar pada kelas Kontrol dan Kelas Eksperimendapat diambil kesimpulan bahwasanya nilai postes kelompok kontrol dengan jumlah keseluruhan nilai yaitu 119,00 dengan nilai rata- rata 8,50. Sedangkan Nilai Postes kelompok Eksperimen keseluruhan nilai yaitu 316,00 dengan nilai rata- rata 21,07. Jadi dapat 
diambil kesimpulan antara nilai postes kontrol dan nilai postes eksperimen setelah dihitung menggunakan uji U hasilnya signifikan.

Peneliti melakukan penelitianterhadap kelas X IPA sebagai Kelas Eksperimen yang berjumlah 15 siswa untuk mengetahui pengaruh Multimedia Flash.

Berikut adalah hasil penilaian nilai pretes pada kelas eksperimen sebelum menggunakan multimedia flash dan nilai postes setelah menggunakan multimedia flash di MA Darul Masholeh Kota Cirebon.

Untuk mengetahui Pengaruh Pembelajaran Ilmu Tajwid Berbasis Multimedia Flash Terhadap Motivasi Belajaryang terjadi signifikan atau tidak maka dihitung menggunakan ketentuan sebagai berikut:

$\mathrm{H} 0: \mu 0=\mu 1$

$\mathrm{H} 1: \mu 1 \neq \mu 0$

Keterangan:

$\mu 0 \quad=$ skor pretest kelompok eksperimen

$\mu 1=$ skor postest kelompok eksperimen

Adapun kriteria yang digunakan untuk melihat diterima atau tidaknya H0 adalah berdasarkan koefisien signifikansi sebagai berikut. Koefisien Signifikansi adalah koefisien yang dihasilkan dari perhitungan uji u

Jika koefisien signifikansi $<\alpha$, maka $\mathrm{H} 0$ ditolak

Jika koefisien signifikansi $\geq \alpha$, maka $\mathrm{H} 0$ diterima

Keterangan:

$\alpha=$ derajat margin of eror besarnya $0,5 \% / 0,05$.

\section{Mann-Whitney Test}

\begin{tabular}{|ll|r|r|r|}
\hline \multicolumn{2}{|c|}{ Ranks } \\
\hline Kelompok & N & Mean Rank & Sum of Ranks \\
\hline Nilai & Pretes Eksperimen & 15 & 8.03 & 120.50 \\
& Postes Eksperimen & 15 & 22.97 & 344.50 \\
\hline
\end{tabular}




\section{Ranks}

\begin{tabular}{|ll|r|r|r|}
\hline Kelompok & \multicolumn{1}{|c|}{ N } & Mean Rank & Sum of Ranks \\
\hline Nilai & Pretes Eksperimen & 15 & 8.03 & 120.50 \\
& Postes Eksperimen & 15 & 22.97 & 344.50 \\
Total & 30 & & \\
\hline
\end{tabular}

\section{Test Statistics ${ }^{\mathrm{b}}$}

\begin{tabular}{|l|r|}
\hline & \multicolumn{1}{|c|}{ Nilai } \\
\hline Mann-Whitney U & .500 \\
Wilcoxon W & 120.500 \\
Z & -4.653 \\
Asymp. Sig. (2-tailed) & .000 \\
Exact Sig. [2*(1-tailed & $.000^{\mathrm{a}}$ \\
Sig.)] & \\
\hline
\end{tabular}

a. Not corrected for ties.

b. Grouping Variable: Kelompok

Dari hasil perhitungan, perbedaan rata-rata data pretest dan data posttest Kelas Eksperimen dengan menggunakan uji U didapatkan nila P-value Sig (2tailed) sebesar 0,000. Karena P-value $<\alpha$, maka H0 diterima dan H1 ditolak. Jadi dapat disimpulkan bahwa pembelajaran Ilmu Tajwid dapat meningkatkan keterampilan belajarsiswa secara signifikan.

Dari hasil diatas, diketahui bahwa nilai signifikansinya adalah 0,000. Nilai signifikansi lebih kecil dari 0,05 artinya bahwa terdapat perbedaan yang signifikan antara nilai pretes dan postes hasil belajar siswa pada kelompok eksperimen. Artinya bahwa terdapat perbedaan peningkatan motivasi belajaryang signifikanpada pembelajaran Tajwidantara siswa yang menggunakan multimedia flash dengan siswa yang menggunakan pembelajaran konvensional.

\section{KESIMPULAN}

Berdasarkan pembahasan dan pengolahan data hasil penelitian pada Bab IV, dapat disimpukan bahwa. 
1. Dari hasil analisis sebelum menggunakan multimedia flash terhadap nilai pretes motivasi belajar pada kelas Kontrol dan Kelas Eksperimen dapat diambil kesimpulan bahwasanya nilai pretes kelompok control dengan jumlah keseluruhan nilai yaitu 244,50 dengan nilai rata- rata 17,46. Sedangkan Nilai Pretes kelompok Eksperimen keseluruhan nilai yaitu 190,50 dengan nilai rata- rata 12,70. Jadi dapat diambil kesimpulan antara nilai pretes kontrol dan nilai pretes eksperimen setelah dihitung menggunakan uji $\mathrm{U}$ hasilnya tidak signifikan.

2. Dari hasil analisis setelah menggunakan multimedia flash terhadap nilai postes motivasi belajar pada kelas Kontrol dan Kelas Eksperimen dapat diambil kesimpulan bahwasanya nilai postes kelompok kontrol dengan jumlah keseluruhan nilai yaitu 119,00 dengan nilai rata- rata 8,50. Sedangkan Nilai Postes kelompok Eksperimen keseluruhan nilai yaitu 316,00 dengan nilai rata- rata 21,07. Jadi dapat diambil kesimpulan antara nilai postes kontrol dan nilai postes eksperimen setelah dihitung menggunakan uji U hasilnya signifikan.

3. Dari hasil analisis sebelum menggunakan multimedia flash terhadap nilai pretes motivasi belajar pada kelas Eksperimen dan setelah menggunakan multimedia flash terhadap nilai Postes kelas Eksperimen, dapat diambil kesimpulan bahwasanya nilai pretes kelompok Eksperimen sebelum menggunakan multimedia flash dengan jumlah keseluruhan nilai yaitu 120,50 dengan nilai ratarata 8,03. Sedangkan Nilai Postes kelompok Eksperimen setelah menggunakan multimedia flash dengan jumlah keseluruhan nilai yaitu 344,50 dengan nilai ratarata 22,97. Jadi dapat diambil kesimpulan antara nilai pretess eksperimen dan nilai postes eksperimen setelah dihitung menggunakan uji $U$ hasilnya signifikan.

\section{SARAN}

Untuk penelitian selanjutnya diharapkan dapat melakukan penelitian yang lebih lengkap,karena peneliti menyadari masih banyak kekurangan dalam penelitian ini. Semoga dengan adanya penelitian ini dapat membantu peneliti selanjutnya supaya lebih baik.

Dalam penulisan skripsi ini penulis menyadari bahwa masih banyak terdapat kekurangan-kekurangan karena segala keterbatasan yang ada baik bekal keilmuan yang penulis miliki serta kurangnya pengetahuan yang menaungi 
penulis. Penyusunan skripsi ini masih jauh dari kata sempurna, baik dari segi isi maupun tata bahasa. Namun dengan kekurangan yang ada semoga dapat memberikan manfaat khususnya bagi penulis dan umumnya bagi pembaca dan sesama rekan mahasiswa.

Penulis berharap semoga skripsi ini bermanfaat bagi pembaca dan penulis khususnya, serta bagi pengembangan Pendidikan Agama Islam (PAI).

\section{DAFTAR PUSTAKA}

Abdullah Asy'ari.1987.PelajaranTajwid.Surabaya:ApolloLestari.

Abu Hazim Muhsin Bin Muhammad Bashory. 2008. Panduan Praktis Tajwid Dan Bid'ah-Bid'ah Seputar Al-Qur'an Serta 250 Kesalahan Dalam Membaca Al-Fatihah. Magetan: Maktabah Daarul Atsar Al-Islamiyah.

Arikunto, Suharsimi. 2010. Prosedur Penelitian: Suatu Pendekatan Praktik. Jakarta: Rineka Cipta.

Arsyad, A. 2002. Media Pembelajaran. Jakarta: PT Raja Grafindo Persada.

Astuti, Dwi. 2006. Macromedia Flash 8. Yogyakarta: Andi.

Bovee. Courland. (1997). Business Communication Today. Prentice Hall : New YorkSurya Brata. 1993. Psikologi Pendidikan. Jakarta. PT. Raja Grafindo Persada.

Dalyono. 2005. Psikologi Pendidikan. Jakarta: Rineka Cipta.

Iswidayati, Sri. 2010.Pemanfaatan Media Pembelajaran Seni Budaya. Semarang: Lembaga pengembangan pendidikan dan profesi UNES.

Maulana.2009. Memahami Hakikat, Variabel, dan Instrumen Penelitian Pendidikan dengan Benar. Bandung: Learn 2 live 'n Live 2 learn.

Munir.2012.Multimedia Konsep dan Aplikasi dalam Pendidikan.Bandung: Alfabeta

Purwanto, Ngalim. 1990. Prinsip-Prinsip dan Teknik Evaluasi Pengajaran. Bandung: Remaja Rosdakarya. 1990. Psikologi Pendidikan. Bandung: Remaja Rosdakarya

Raharjo, Hendri, 2009, Suplemen Multimedia Pembelajaran Berbasis Komputer,Cirebon:CV Pangger.

Sagala, S. 2006. Konsep dan Makna Pembelajaran. Bandung: CV. Alfabeta. 
Sardiman, A. M. 2005.Interaksi dan Motivasi Belajar Mengajar.Jakarta: PT. Rajagrafindo Persada.

Sei. H. DY. Tombak Alam.2002. “Ilmu Tajwid Populer” 17 Kali Pandai. Jakarta: Bumi Aksara.

Sugiyono.2013. Metode Penelitian Kuantitatif, Kualitatif, Dan Kombinasi (Mixed Methods). Bandung: CV. Alfabeta.

Supranto, J. ( 2002 ). Statistik Teori dan Aplikasi. Jakarta: Erlangga.

Sutrisno, Hadi. 1989. Metodologi Riset.Yogyakarta : . Andi Offset

Suyanto. 2005. Pengantar Teknologi Informasi. Yogyakarta:CV Andi Offset.

Wiroatmojo, P dan Sasonoharjo. 2002. Media Pembelajaran. Jakarta: LAN RI 